\title{
Analysis of Learning Problems in Chemistry at Eria Medan Private High School
}

\author{
Rafika Utami ${ }^{{ }^{*}}$ \\ ${ }^{1}$ Department of Bilingual Education, Faculty of Mathematics and Science, State University of Medan, Indonesia \\ *Corresponding author: rafikautami1@gmail.com
}

\begin{tabular}{l} 
A R T I C L E I N F O \\
Article history: \\
Received date : 30 May 2018 \\
Revised date : 31 July 2018 \\
Accepted date: 8 August 2018 \\
Available online at : \\
http://inajac.lipi.go.id \\
\hline $\begin{array}{l}\text { Keywords: } \\
\text { Problem of learning chemistry, } \\
\text { Learning process, Teaching } \\
\text { strategies, Misconception }\end{array}$
\end{tabular}

\section{INTRODUCTION}

Teaching and learning process is one of the most dominant efforts in improving the quality of education in Indonesia. The process of teaching and learning is essentially a communication process. Communication process is the process of conveying information from information sources through certain channels or media to the recipient. The information is in the form of teaching content and the instruction contained in the curriculum. In essence, the process of teaching and learning is a system that composed of various components: teachers, learners, lesson materials, methods and teaching strategies, media, learning resources and evaluation that work together and integrate to achieve learning objectives [1]. Therefore, the process of teaching and learning must be effective in order to obtain maximum results, and that can be applied in the daily life. Effective learning requires strategies or approaches that can attract students' attention in learning materials and can facilitate students to understand the material in the learning process

Chemistry is one of natural science subjects that is given to senior high school students. Several researches shows that science, especially chemistry and physics is one of the less favored subjects among students. One reason is that in science, especially chemistry, many concepts were abstract things, such as the concept of atoms, oxidation numbers, equations of reactions, and energy. According to Gabel, this abstract concept makes chemistry a complex lesson. This creates a lot of problem for the students. In addition, the creativity of teachers in teaching, and strategies or the methods they use also affect students' interest in learning. If the teaching method or strategy is unattractive and tends to be boring, the student will feel bored and feel that the chemistry lesson is a difficult and uninteresting lesson.

In addition, most teachers only emphasize on the calculation rather than understanding 
the concept. So, many students suffer from misconception in understanding the subject matter of chemistry

Based on the above description,inhibiting factors in the success of the chemical learning process should be identified. Therefore, the authors conducted a research in Eria Medan private high school to analyze the problems that occur in the process of learning chemistry and the delivered teaching methods. The objective of this research is to provide an overview of problems that occur in the learning process of chemistry at Eria Medan Private High School.

\section{EXPERIMENTAL SECTION}

This research used a descriptive qualitative method, which describes the data as it is and analyze the questionnaire of student responses with qualitative explanation sentences [2].

This research was conducted in Eria Medan Private High School, and the subjects are student of Mathematics and Natural Science 1 class XI.

Data were collected using observation sheet form and questionnaire student responses were recorded. To obtain data about teacher activity during the learning activity, the researcher used an observation instrument. The observation instrument is an observation format containing the events or behaviors described. Observation is one method that can be used to obtain information about the research focus. The focus of observation can be events, behaviors and expressions. In this method, the researchers need to sensitively asses the situation or setting. where he or she made observations. Researchers observed teacher activities in the classroom when chemistry learning takes place.

To obtain students' responses to chemistry lessons, researcher used the questionnaire instrument. The questionnaire consisted of 15 questions (see appendix). And to obtain data of teacher activities, researcher used the observation sheet (see appendix).
Data analysis used is descriptive interpretative data analysis. The data obtained are presented in tabular form, percentage and narrative descriptions.

Data on learning activities and response were analysed using the percentage formula as in Equation (1).

$$
\text { Score }=\frac{\text { Score Earned }}{\text { Maximum Score }} \times 100 \%
$$

Data on teacher activities was analysed using the percentage formula as in Equation (2).

$$
\text { Score }=\frac{\text { Score } \text { Earned }}{\text { Maximum Score }} \times 100 \%
$$

With the criteria :

\begin{tabular}{|c|c|}
\hline Criteria & Score $(\%)$ \\
\hline Very Good & $76-100$ \\
\hline Good & $51-75$ \\
\hline Good enough & $26-50$ \\
\hline Less & $1-25$ \\
\hline
\end{tabular}

\section{RESULTS AND DISCUSSION}

\subsection{Data of Student Responses}

Based on the results of questionnaire data given to each class XI on Mathematics and Natural Science 1 students, obtained some data that learning chemistry in class XI on Mathematics and Natural Science 1 is good enough. However, there are some problems that are the inhibiting factors in success in the chemistry learning process.

The first problem is low student motivation in chemistry learning. The data description explained that $62.85 \%$ of students prefer chemistry but only $37.14 \%$ of students were happy to complete or practice with questions and $42.85 \%$ of students were actively involved in the learning process. This shows that students were quite happy with chemistry lessons but did not fully like chemistry lessons. This is due to lack of motivation. Therefore, it is necessary to have a learning method that can change the learning style of students from passive learners to be active in constructing concepts and analyzing problems so that students are accustomed to think critically [3]. Teachers should be able to provide more effective learning methods that can arouse 
students attention so that students become active and motivated to learn, and must be balanced with the ability of teachers in mastering the method. Likewise, the chemical subjects were abstract. Teachers can make students feel interested and motivated in various ways, one of them is by using approaches and instructional media in accordance with the material that will be taught so that students can think critically, logically, solve problems with open attitude, creative and innovative and not boring [4].

The second problem is the chemistry book used as a learning book was less interesting to read. Based on the data, $80 \%$ of students said the book is less interesting and only $20 \%$ of students who stated their chemistry book interesting to read. This shows that the use of books as one of learning resource is also very important to pay attention for, because students' who are interested in chemistry textbooks could help in the success of learning process. If students are interested and feel happy to read the textbooks, it will facilitate active learning in the classroom because students and teachers will interact actively.

The results of the percentage of responses given by students in detail are shown in the following tables and graphs:

Table 1. The results of the percentage of responses.

\begin{tabular}{|c|c|c|c|c|}
\hline No. & Questions & $\begin{array}{l}\text { Yes } \\
(\%)\end{array}$ & $\begin{array}{c}\text { Less } \\
(\%)\end{array}$ & $\begin{array}{l}\text { No } \\
(\%)\end{array}$ \\
\hline 1. & Are you interested in chemistry subjects? & 62,85 & 31,42 & 5,71 \\
\hline 2. & Are you active in classroom learning? & 42,85 & 57,14 & 0 \\
\hline 3. & $\begin{array}{l}\text { Do you enjoy trying to understand concepts and working on problems } \\
\text { independently? }\end{array}$ & 54,28 & 40 & 5,71 \\
\hline 4. & $\begin{array}{l}\text { Are you happy or interested in trying to solve problems in practice about } \\
\text { different variations of questions? }\end{array}$ & 37,14 & 51,42 & 11,42 \\
\hline 5. & $\begin{array}{l}\text { Have you ever found any weaknesses or mistakes that others have made } \\
\text { in solving a problem or task? }\end{array}$ & 62,85 & 17,14 & 20 \\
\hline 6. & Do you often express opinions in the learning process or discussion? & 37,14 & 45,71 & 17,14 \\
\hline 7. & Are you happy to be actively involved in group discussions? & 88,57 & 11,42 & 0 \\
\hline 8. & Did you immediately complete the assignment without delay? & 65,71 & 31,42 & 2,85 \\
\hline 9. & Do you conclude the learning materials in your own words? & 40 & 42,85 & 17,14 \\
\hline 10. & Did you record the material presented by the teacher? & 94,28 & 5,71 & 0 \\
\hline 11. & $\begin{array}{l}\text { Do you have difficulty understanding the lessons (chemistry) presented } \\
\text { by the teacher? }\end{array}$ & 31,42 & 51,42 & 20 \\
\hline 12. & Are you trying to understand the chemicals presented? & 100 & 0 & 0 \\
\hline 13. & Do you understand the lessons (chemistry) presented by the teacher? & 65,71 & 34,28 & 0 \\
\hline 14. & Is your chemistry book interesting to read? & 20 & 80 & 0 \\
\hline 15. & Is the use of the language in your chemistry book easy to understand? & 57,14 & 8,57 & 34,28 \\
\hline
\end{tabular}




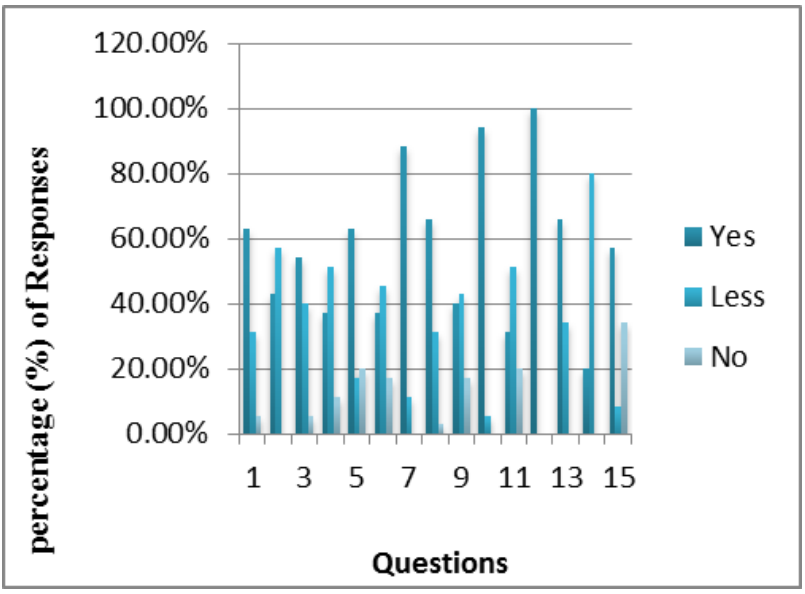

Fig. 1. Graphic of Percentage of Students Responses.

\subsection{Observation Teacher Activity}

Based on the observation data of teacher activity in class, we obtained information that from total of 20 items that investigated, there are 15 items that appropriate to the criteria, 4 items that less appropriate to the criteria and 3 items that do not appropriate to the criteria. The items in the teacher activity observation instrument can be seen in the appendix section.

Data that less appropriate to the criteria:

1) Teachers are less prepared learning tools.

2) Teachers did not relate material application in everyday life.

3) Teachers have enough mastery on the teaching material but there was misconception in the mastery of the material.

4) The teacher is quite clear in presenting the material but there was a misconception that when the teacher explained the matter of equilibrium reaction, the teacher did not explained the phases contained in the reaction equation.

Data that do not appropriate to the criteria:

1) Teacher did not used props in the learning process.

2) Teacher did not provided concrete examples in the events that exist in life in accordance with the tools exhibited because there is no props used in the learning process.

The result of observation of teacher activity showed that the learning activity conducted by chemistry teacher in the classroom as a whole fulfilled the good category, because based on the calculation using percentage formula obtained the observation of teacher activity with the percentage of activity $75 \%$, which means the teacher activity in the class in good category $(51 \%-75 \%)$. However, the learning process of chemistry is still largely teachercentered. In addition, teachers still use lecture methods so that students tend to be passive which leads to lack of student motivation in chemical learning activities. Teacher centered teaching is now no longer suitable because in this method, teachers only transfer knowledge to students and it has always been used as a means of oral communication between teachers and students in interaction educational [5]. This method is more demanding teacher activeness than the students. The use of monotonous teaching methods such as lectures, may lead to drowsiness and less students attention because boringness. It is seen from the questionnaire results where most students still feel less in understanding the chemistry lessons that have been taught by teachers.

In addition, the use of lecture methods in the learning process has several disadvantages as follows: Since the model is teacher-centered, the success of learning depends on the teacher. If the teacher is lacking in preparation, knowledge, confidence, enthusiasm then the student can become bored, distracted, and learning will be hampered. The lecture method relies heavily on the way the teacher communicates. If teachers cannot communicate well then will make learning less good as well. If the material presented is complex, detailed or abstract, the direct learning model cannot provide an opportunity for students to adequately process and understand the information presented. If using too often the lecture method will make the assumption that the teacher will tell the students all the information that needs to be known. This will eliminate the sense of 


\section{pp. 26-30, August 2018}

responsibility about the student's own learning [6].

In essence, on the learning process is not a media delivery of information in one direction, but is a system, which in it has a variety of components that work together and integrated to achieve learning objectives. These components are the objectives of teaching, teachers and learners, lesson materials, teaching methods and strategies, tools or media, learning resources and evaluation [7].

\section{CONCLUSION}

Based on results of this study, therefore some conclusions are drawn as below:

1) Student have low motivation in chemistry learning.

2) Chemistry book used as a learning book less interesting to read.

3) Teacher did not relate material application in everyday life.

4) There are misconception in reaction in chemical equilibrium.

\section{REFERENCES}

[1]. Munandar, $\mathrm{H}$ and Jofrishal. Analisis Pelaksanaan Pembelajaran Kimia Di Kelas Homogen," Lantanida Journal, vol. 4, pp. 99-108. (2016)

[2]. Mentari. L., Suardana, I., Subagia, I. Analisis Miskonsepsi Siswa Sma Pada Pembelajaran Kimia, e-Journal Kimia Visvitalis, vol. 2, pp. 77-78. (2014).

[3]. Afriaawan, M. Pengaruh Penerapan Pendekatan Savi Bervisi Sets Pada Pencapaian Kompetensi Terkait Reaksi Redoks," Unnes Science Education Journal, vol. 2, pp. 51-59. (2012).

[4]. Achmad. Pengaruh Media Permainan Truth And Dare Terhadap Hasil Belajar Kimia Siswa SMA Dengan Visi Sets," Jurnal Inovasi Pendidikan Kimia, vol. 1, pp.230-235. ( 2008).
[5]. Ristiyanti, E and Bahriah, E. Analisis Kesulitan Belajar Kimia Siswa Di Sman X Kota Tangerang Selatan," Jurnal Penelitian dan Pembelajaran IPA, vol. 2, pp. 19-22. (2016).

[6]. Ridho, N. Model Pembelajaran Langsung," Artikel Pendidikan. (2011).

[7]. Arikunto, S. Prosedur Penelitian. Jakarta : PT. Rineka Cipta. (2007). 